\title{
Correction to: Demarcation of groundwater quality domains using GIS for best agricultural practices in the drought-prone Shanmuganadhi River basin of South India
}

\author{
P. Aravinthasamy ${ }^{1} \cdot$ D. Karunanidhi ${ }^{1} \cdot$ T. Subramani ${ }^{2} \cdot$ Priyadarsi D. Roy $^{3}$ \\ Published online: 18 May 2020 \\ (C) Springer-Verlag GmbH Germany, part of Springer Nature 2020
}

Correction to: Environmental Science and Pollution Research https://doi.org/10.1007/s11356-020-08518-5

The correct name of the $1^{\text {st }}$ Author is presented in this paper. The original article is corrected.

The online version of the original article can be found at https://doi.org/ $10.1007 / \mathrm{s} 11356-020-08518-5$

\footnotetext{
D. Karunanidhi

karunasamygis@gmail.com

1 Department of Civil Engineering, Sri Shakthi Institute of Engineering and Technology (Autonomous), Coimbatore 641062, India

2 Department of Geology, CEG, Anna University, Chennai 600025 , India

3 Instituto de Geologia, Universidad Nacional Autonoma de Mexico (UNAM), Ciudad Universitaria, CP 04510 Mexico City, Mexico
} 